\title{
Conservation Facing the Uses Knowledge of Phacochoerus Africanus (Gmelin 1788), Common Warthog And Potamochoerus Porcus (Linnaeus 1758), Red River Hog In South Of Benin
}

Florian Gbodja Codjia ( $\sim$ floriancodjia781@gmail.com )

University of Agriculture of Kétou: Universite Nationale d'Agriculture https://orcid.org/0000-0002-71931182

Toussaint Olou Lougbegnon

University of Agriculture of Kétou: Universite Nationale d'Agriculture

Sérgio de Faria Lopes

Universidade Estadual da Paraiba

Guy Apollinaire Mensah

INRAB

\section{Research}

Keywords: use categories, wild suids, local population, west Africa

Posted Date: January 29th, 2021

DOI: https://doi.org/10.21203/rs.3.rs-156828/v1

License: (c) (1) This work is licensed under a Creative Commons Attribution 4.0 International License.

Read Full License 


\title{
Conservation Facing The Uses Knowledge Of Phacochoerus Africanus (Gmelin 1788), Common Warthog And Potamochoerus Porcus (Linnaeus 1758), Red River Hog In South Of Benin
}

\author{
Florian Gbodja Codjia 1*, Toussaint Olou Lougbegnon ${ }^{12}$, Sérgio de Faria Lopes ${ }^{3}$ Guy Apollinaire \\ Mensah $^{4}$ \\ 1 - Laboratoire de Recherche en Ecologie Animale et Zoogéographie (LaREZ), Université Nationale \\ d'Agriculture, BP 43, Kétou, Bénin. \\ 2 - Ecole de Foresterie Tropicale (EForT), Université Nationale d'Agriculture, BP 43, Kétou, Bénin. \\ 3 - Universidade Estadual da Paraíba, Departamento de Biologia, Neotropical Ecology Lab - EcoTropics, Brazil \\ 4 - Institut National des Recherches Agricoles du Bénin, Centre de Recherche d'Agonkanmey (CRA/ \\ INRAB), Abomey-Calavi, République du Bénin. \\ *Auteur correspondant : floriancodjia781@gmail.com ; Tél : (+ 229) 65423325
}

\begin{abstract}

\section{Background}

Despite the number of wild animals that are useful to the local population and have served as a basis for ethnozoological research in Benin, others such as Phacochoerus africanus and Potamochoerus porcus remain poorly documented according to their uses. They are already facing threats to their proper conservation in ecosystems where they are found in metapopulations as a result of the fragmentation effects. In this study, the ethnozoological knowledge of these suids in southern Benin was inventoried.
\end{abstract}

\section{Methods}

To achieve this objective, structured interviews were conducted with 138 people randomly selected in nine districts. The use values of these suids parts and the fidelity level were assessed through global ethnozoological value. Non-parametric tests were carried out to analyse the uses differences according to gender, age and ethnic group. Two Correspondence Analyses (PCA) were carried out to describe use categories within districts and ethnic groups. A Generalized Linear Model (GLMs) of binomial families was used to relate the suids practice hunting to districts and distance from the village.

\section{Results}

More than two use categories (food, medicinal and magical) were identified for both species. With regard to the most commonly used parts, we have the mane, teeth, horns for the common warthog and the skull, teeth, nose and testicles for the red river hog. Ten illnesses were cited 
to be treated by their parts. Significant differences were observed between ethnic groups regarding the suids medicinal uses but not for gender. The ethnozoological use value of suids was almost similar for adults and the elderly.

\section{Conclusion}

Strong pressure continues to be exerted on these two suids and their habitats despite their high zootechnical potential compared to exotic pigs. After the creation of income-generating activities, future research needs to be carried out to evaluate their budgets activities, genetic study and diet through metabarcoding approaches to promote their domestication. This could help to capitalise data that can be used in breeding programmes in order to limit threats on the few species individuals found in the natural environment, as well as to participate in reintroductions if necessary.

Keywords: use categories, wild suids, local population, west Africa.

\section{INTRODUCTION}

Following the ancient times example, when humans materialised the animal species presence through drawings and signs, there is still a particular interest in translating the relationships [1], [2] with this biodiversity life form. Following the example of marine molluscs [3], animals continue to be used by humans for various decorative, food, magical-religious and medicinal purposes [4], [5]. Although plants and their derivatives are more often used in traditional and modern medicine, various cultures in Africa and around the world use animals for specific uses justifying their presence in pharmacopoeia [5]. The emergence of traditional medicine in Africa is no longer in doubt, where its demography is growing today and future projections are three times as high. The use of this fauna in food, in the treatment of certain religious, medicinal and magical problems [6] often requiring abusive and irrational harvesting in nature reserves, even if a fringe of users resort to domestication.

Several species such as suids have become prime targets and formal hunting, poaching activities keep on being the main sources of income for the local population [7], [8]. As a result, there has been a decline crises series in most of the world's wildlife populations. They existed and continue to take root because of habitat fragmentation, lack of economic alternatives, overexploitation of resources, population growth, inadequate land management and practices, and political-social conflicts [9], [10]. Consequently, according to Alves \& 
Alves, (2011), degradation in endogenous knowledge contributes to many concerns about wildlife conservation.

Several animal species in Benin, Africa and even invertebrates are cited in traditional medicine in the treatment of many diseases and for purposes emanating from mystery [12], [13]. Phacochoerus africanus (Gmelin 1788), Potamocheorus porcus (Linnaeus 1758) and Sus scrofa domesticus are the main suids found in Benin [14]. Among the research work carried out in ethnozoology in this country, none has yet focused on suids. The work results relating to traditional knowledge continue to be ignored in science [15] yet ethnozoological approaches seem essential to complement fundamental research by better defining, according to cultures, the socio-ecological aspects of the roles played by animals [16]. It is therefore essential to study the main uses made by the local population of the lesser-known suid species found in Benin and which are in a threatened state, to better guide conservation strategies for this taxonomic group.

Suids provide a wide range of economic, social and ecological benefits to people and contribute to household incomes [7]. However, they can cause damage to humans [17] and crops [18]. They are found in different habitats depending on the species and are well known as seed dispersers [19], which makes them of major interest about the floristic structure of tropical forests and savannahs. They are subject to threats in their occurrence areas. As a result, since the 1995's some wild pig species have become critically endangered [20] and their population is currently in decline [21], [22]. The species found in Potamochoerus and Phacochoerus gender are highly valued for their meat and they are also quite prolific.

This study aims to inventory the ethnozoological knowledge of Phacochoerus africanus (Gmelin 1788) and Potamochoerus porcus (Linnaeus 1758) by socio-cultural groups in southern Benin. Some questions were raised to support our goals: Are they some differences in knowledge between genders, age and ethnic group ? Are the suids parts much more involved in magical uses? Is there a consensus around the desire to conserve these suids in the face of their diverse importance? At the end of this study, it will therefore be proposed new conservation options in order to reduce the threats level within their population.

\section{MATERIAL AND METHODS}

\section{Study area}

The study sites extend between latitudes $8^{\circ} 00^{\prime}$ and $7^{\circ} 12^{\prime} \mathrm{N}$ and longitudes $1^{\circ} 36^{\prime}$ and $2^{\circ} 48^{\prime} \mathrm{E}$ (Fig. 1) with an average of 2.250 .000 ha. This is charactized by two climatic zones: the 
Sudano-Guinean transition zone and the Guinean zone. The first is characterized by shrubby/wooded savannah, forest galleries and fallow fields. Semi-deciduous dense forests, swampy formations, and thickets are often found in the Guinean zone in addition to fields. The choice of sites inventoried was based on the various results of our surveys and previous work where the presence of these suids was confirmed in Benin. Among these works we are those of [23]-[26]. The work of [14] show that in addition to the low representativeness of the Guinean zone, the transition zone of Benin, on the other hand, is a determining factor in the explanation of these two sympatric species. Also from the works of [27], a severe degradation of the vegetation cover is noted in the Benin southern part due to a high concentration of more than half of the population.

The Lokoli swamp forest is located in the district of Koussoukpa, (commune of Zogbodomey) between $7^{\circ} 03^{\prime} \mathrm{N}$ and $2^{\circ} 15^{\prime} \mathrm{E}$ on an area of about 3000 ha. The average annual temperature is between 26 and $28^{\circ} \mathrm{C}$. In the Guinean zone, the gazetted Lama forest extends between latitudes $6^{\circ} 55^{\prime}$ to $7^{\circ} 00^{\prime} \mathrm{N}$ and longitudes $2^{\circ} 04^{\prime}$ to $2^{\circ} 12^{\prime} \mathrm{E}$ halfway between Allada and Bohicon. The southern part of this forest is accessible by the Ouègbo-Toffo trail while to the north, an Agrimey-Koto trail leads to the edge of the forest. The climate in southern Benin is sub-equatorial with four seasons unevenly distributed. The Gbidji swamp meadow is located in the commune of Dévé within the Mono Biosphere Reserve which is between latitudes $6^{\circ} 11^{\prime} 14.2^{\prime \prime}$ and $6^{\circ} 59$ '58.7" $\mathrm{N}$ and between longitudes $1^{\circ} 35$ '47.1" $\mathrm{E}$ and $1^{\circ} 59^{\prime}$ 28.1" E. It is an integral part of the RAMSAR 1017 site. The main habitats types found in the study area are: Dense semi-deciduous forests, swampy formations, open forests, wooded savannas, mosaics of fields and fallows, swampy meadows, plantations. The Gnanhouizoun Community Area is found in the village Gnanhouizounmè located in Damè-Wogon district (Bonou commune) with an area of 25.33651 ha. The commune of Bonou is located in the Department of Ouémé between $6^{\circ} 72^{\prime}$ and $6^{\circ} 95^{\prime}$ north latitude and between $2^{\circ} 15^{\prime}$ and $2^{\circ} 40^{\prime}$ east longitude. The Agbé and Mongnigbé Complex is located in the Zou department while the Djaloukou Ranch in the hills. The Sédjè Denou and Houegoudo Complex is located in the Atlantic Department, more precisely in the Zé commune. We finally have the Gazetted DogoKétou Forest and the Sacred Forest of Kouvizoun which are located in the Plateau department (Fig. 1). The main soils encountered in this study area are hydromorphic, ferruginous, ferralitic, sandy loam, colluvial, alluvial and vertisol [28].

\section{Data collection method}


Different socio-professional categories were considered during the preliminary studies among 30 people found in the southern Benin protected areas where the presence of Phacochoerus africanus and Potamocheorus porcus are reported. The different socio-professional categories included: veterinarian, shopkeeper, processor of agricultural products, hunter, forest operator, fisher, farmer, ecological guide and breeder (Fig. 2). During the preliminary step, AgbéMongnigbé complex, Gnanhouizoun-CA and Gbidji swampy meadow were considered. The number 30 (binomial distribution) has been used to approximate the normal distribution. It was then determined the proportion of people that have knowledge on these two species and have had at least one direct contact with them. The information was used to calculate the sample size (n) to be surveyed according to the normal approximation equation of the binomial distribution [29]:

$$
n=\frac{U_{1-\alpha / 2}^{2} \times p(1-p)}{d^{2}}
$$

where $n$ is the sample size per selected village, $\mathrm{p}=0.24$ is proportion of residents aware of the current suids presence, $U 1-\alpha / 2$ is the standardized value with a probability p equals 1- $\alpha$ / 2 for a probability of 0.95 (with $\alpha=0.05, \mathrm{U} 1-\alpha / 2 \approx 1.64$ ) and $\mathrm{d}$ is the margin of error of the measured parameters however a standard error of $6 \%$ will be considered for this study. A total of $n=138$ people from these different socio-professional categories and ethnic groups were interviewed. The stratified method was used among the probability sampling methods, considering the districts and localities of each study site. Some of the respondents characteristics are summarised in Table 1.

The surveys were carried out from 15 December 2019 to 29 March 2020 in nine sites. Questions on the different uses of these suids, their socio-economic and cultural importance were asked to all socio-professional groups considered without distinction of gender and age [30]. Data collection was carried out using semi-structured interviews based on a questionnaire developed for this purpose. These were open-ended and closed-ended questions relating mainly to the behaviour of local communities towards these suid species. These surveys were conducted in French as well as in local languages with the help of an interpreter when necessary and whenever possible. Scores (0 to 3 ) were assigned to each specific use category according to the frequency of use and respectively according to whether the species is: highly used $=3$, fairly used $=2$, weakly used $=1$, not used $=0$ [31], [32].

\section{Data analysis}


To analyse the main data of this study, ethnozoological parameters were calculated. It's the case of the Fidelity Level (FL): The fidelity level which was calculated with the use categories and the different parts of suids used in order to assess the suids species importance following the formula [33]: $\mathrm{FL}=\frac{n}{N} * 100$

with n: number of people that provided an answer in relation to a given use or a given part use; N: total number of people surveyed for the given species (common Warthog, Red river hog).

We have also the ethnozoological value (UV) which was determined for each ethnic, gender and age group by use categories (k) according to Philips \& Gentry, (1993): $U V_{k}=\frac{1}{n} \sum_{p=1}^{n} S$ where $\mathrm{S}$ is the score assigned by respondents to a given use category and $\mathrm{n}$ is the number of respondents. At last about indices, the Global ethnozoological value (OUV) was determined for each ethnic, gender and age group following this formula : $\mathrm{OUV}=\sum_{i=1}^{k} U V_{k}$ where $\mathrm{k}$ is the number of use category, $\mathrm{UV}_{\mathrm{k}} \mathrm{s}$ the ethnozoological value of the species for a use category $\mathrm{k}$ by ethnic group, sex and age.

The normality and homogeneity of the use value was checked and in the case of nonnormality the non-parametric tests were done to see the differences relating to gender, age and ethnic group. The relative citation frequency according to use categories for each species was presented as a barplot using the ggplot2 package. Similarly for the relative citation frequency for the suids parts used, the current uses per species are presented. Two Correspondence Analysis (PCA) carried out with the FactoMineR package described the use categories within districts on the one hand and within ethnic groups on the other. A generalised linear model (GLMs) of the binomial family was used to relate the species practice hunting to districts and distance from the village. The test from $\chi^{2}$ was used to assess the fit of the GLMs to the data and the pseudo-coefficient of determination $\mathrm{R}^{2}$ [35] was calculated with the fmsb package [36] to assess the explanatory power of the data models. In addition, the reasons for the conservation of the species were presented with barplot. All these analyses are carried out with the statistical software R.

\section{RESULTS}

\section{Suids use categories}

Three categories of suids use, for food, medicinal and magical purposes were recorded in this study. Food use was the most dominant category. The Fidelity Level representing the frequency of citation by use category for each suid species is shown in Fig. 3. All informants 
surveyed in areas where common Warthogs are present used the species for food, while $54.54 \%$ and $18.18 \%$ exploited the species for medicinal and magical purposes respectively. For the informants in the areas where Red river hog are found $91.80 \%$ use it as a protein food source, as well $10.65 \%$ and $27.85 \%$ respectively for magic and medicine.

\section{Use categories of suids for medicine and magic}

The different parts of the suids that were involved in traditional medicine and magic are presented in Table 2 according to their Fidelity Level (FL). The results showed that for common Warthogs, the most used parts are mane $(\mathrm{FL}=18.2 \%)$, teeth $(\mathrm{FL}=18.2 \%)$, and horns ( $\mathrm{FL}=18.2 \%$ ) to treat fertility, strengthen bones in newborns, fight witchcraft and make children resistant to diseases. Among the Red river hogs, the skull (21.2\%), teeth $(18.8 \%)$, nose $(6.6 \%)$ and testicles $(3.3 \%)$ are used much more to treat headaches, hernias, promote rapid teething in children, toothache, sexual weakness and infertility. So these two species are very little used in magic.

\section{Variation in knowledge by gender, age and ethnic groups}

The use value by gender, age and ethnic groups is presented in Table 3 and 4. Significant differences were observed between ethnic groups regarding the medicinal uses of suids. The Nagots considered the species to be a taxon of high medicinal value. Finally, informants from different age groups presented equal knowledge for suids regarding its use for medicinal, feeding and magical purposes. The ethnozoological use value of suids was almost similar across age classes (OUV $30<$ years $\leq 60=0.13$ and OUV $>60$ years $=0.19$ ). No significant differences were observed in the gender distribution of the different use categories, however, showing that the informants used the species in almost the same way according to gender.

\section{Hunting pratice following the district}

The results of the binomial regression (Table 5) showed that the district and distance from the village explained $40.61 \%$ of the variation in hunting practice $\left(\chi^{2}(89)=5,42, \mathrm{P}=1, \mathrm{R}^{2}=\right.$ $40,61 \%)$. But only the district had a considerable influence $(\mathrm{P}<0.05)$ on hunting practice. Thus 85\%, 87.18\% and 88.46\% of the informants from Koussoukpa, Agbokpa and SedjeDenou respectively acknowledged the practice of hunting suids in their localities as can be seen from the Fig. 5.

\section{Reasons related to species conservation}


The majority of the informants $(79.71 \%)$ expressed the need to keep the suids. The desire to keep these suids varied considerably according to the district. According to figure 6, only $0.91 \%$ of the informants in Idigny, Ayomi were thinking of keeping suids. While informants in Massi (30.91\%), Koussoukpa (29.09\%) and Sedje-Denou (16.36\%) expressed the need to conserve the species mainly. The reasons for the desire to conserve suids are presented in Fig. 7. The reasons behind this enthusiasm were particularly the interest of their protection for the future generation $(51.8 \pm 9.34 \%)$, their medicinal virtues $(11.8 \pm 6.03 \%)$ and for tourism $(8.2 \pm$ $8.18 \%)$.

\section{DISCUSSION}

\section{Use and category use of common Warthog and Red river hog}

The use of zootherapeutic techniques through ethnozoological knowledge is a fairly common practice in Africa and particularly in South Benin as the work of [16], [37] has shown. It is true that many studies have not been carried out directly on the ethnozoological values of suids, but some authors such as [38]-[40] have alluded to the use of certain parts of them when studying other fauna species. In this study, and also observed in several works [15], [41], parts/products of the Red river hog and common Warthog were identified by local experts as useful for food, medicinal and magical uses. In this study, food use was the most favoured species of suids ( $100 \%$ of cases for common Warthog $\pm 91.80 \%$ for Red river hog). This can be explained as follows they are game of choice due to their numerous organoleptic qualities [8], [42] and serve as an income for the population to survive during the most difficult times [7], [43]. Although Muslims are not in the majority in Benin, nor in the part covering the study area, certain religious beliefs, primarily the 'Thron', have not influenced their consumption. In addition to food use, medicinal properties prevail over magical properties, whether it is for the Red river hog or the common Warthog in this study. Indeed, the work of [40] shows the importance of common Warthog in the medicinal ailments treatment. As for the red river hog, the work of [38], on the other hand, presents it as an animal with great ethnobiological values and whose parts/products are used in traditional rites and practices. The magical use of these two suids is hardly surprising because since ancient times the pig has been an animal linked to many religious myths, including Muslim ones. The most parts involved in the realisation of these different medicinal and magical properties were respectively for the common warthog, the mane, the teeth, the horns and for the Red river hog, the skull, the teeth, the nose, the testicles. The common Warthog and Red river hog parts 
used in traditional medicinale, magic pratice with theirs productions methods are presented in Table 6.

Better known as living in sympatry [44] in certain habitats, this study also shows that the parts used in common for both species in the realisation of certain medicinal and magical uses are the teeth, the bones, the hooks. These were used to strengthen newborn baby bones, make children hardy to disease, against witchcraft, promotes rapid teething in children, toothache, sickle cell disease, erecting the vodoun Gou. The results of the work carried out in North-Western Ethiopia and South-Western Cameroon do not really deviate from our realities by reflecting the importance of teeth respectively for toothache, swelling, rheumatism and the announcement of bad news, prestige in traditions [38], [40].

To benefit from all these properties, hunters take advantage of these suids depredation cases caused by shooting them [5], [7] or even deliberately of their own free will (Fig. 6).

\section{Variation in knowledge and reasons for conservation}

Some differences were observed between ethnic groups regarding the medicinal uses of suids under the strong contribution of the Nagots in this study. Indeed, the Nagots were dominant in the sample from which our informants came. The majority of these informants were farmers and hunters that had other secondary activities and had sufficient knowledge about these suids in the medicine and magic field. Furthermore, we know that the Nagot ethnic group is very similar to the Yoruba ethnic group and has the same cultural and religious practices. The work of [45]-[47] has shown that the Yoruba ethnic group is much more in favour of the traditional values conservation also in the field of medicine from one generation to another, especially through men.

It is easy to understand the Nagots' high regard for these suids in the light of the results obtained. The use of parts or products of these suids was not only the prerogative of people of a certain age and social position as reflected in the work of [48]. In contrast to the results of [16] on the common hippopotamus in south Benin and those of [49], [50] on medicinal plants, 
this study showed that the global ethnozoological use value was almost similar across age groups (OUV $30<$ years $\leq 60=0.13$ and OUV $>60$ years $=0.19)$. The younger people involvement by adults and older people in the knowledge acquisition which becomes higher and higher across the generations could explained this last result. This is all the more remarkable with the strong contribution of the Nagot ethnic groups (grouped in the districts of Idigny, Djaloukou and Massi), Fon and Aïzo.

Medicinal uses were mainly the prerogative of the Nagot and Aïzo (Fig. 8) in the districts of Djaloukou, Sedje-Denou and Massi, while magical uses were mainly the work of the Adja, Mahi and Wéménou in the districts of Deve, Adakplame, Dame-Wogon and Agbokpa (Fig. 9). Food uses were observed among the Fon, mainly in the districts of Koussoukpa and Idigny. The values of ethnozoological uses for this suids taxon vary according to age and ethnic group.

In addition to the medicinal virtues, the reasons for choosing to conserve these two suids species were mainly their protection for future generation and tourism. Indirectly translating the conservation level as well as possible conservation actions in these occurrence areas of the common Warthog and Red river hog. These results are consistent with those observed in the work of [51] carried out in the Mono Biosphere Reserve on the common hippopotamus. The work of [52] also shows the enthusiasm of the local population for conserving biodiversity for future generations. Indeed, the involvement of the local population in the governance and comanagement of biodiversity reservoirs in Africa and around the world continues to yield quite positive results, as proven in the work of [53]. Unfortunately, the Covid-19 pandemic continues to have a negative impact on the income-generating activities [54] of the local population, circumstantially tainting this desire for sustainable conservation. Concerted management keep on being important, but it is also urgent to create new generating activities for the local population while waiting for the end of this pandemic for sustainable conservation.

\section{CONCLUSION}

A diverse use of the different parts/products of common warthog and red river hog: food, magic and medicinal was presented in this study. A variation in the use of the two species was also noted according to socio-cultural groups. Apart from their consumption, two trends were relatively observed in southern Benin. Some (Nagot and Aïzo) gave great medicinal importance to the species, while others (Adja, Mahi, Wéménou) gave even greater importance 
to the species for magical purposes. Sustainable conservation of these two species could be based on effective consideration of all aspects of the this work results. The most used parts for both species are the teeth, bones, and hooks. Strong pressure continues to be exerted on these two suids and their habitats despite the high zootechnical potential they present compared to exotic pigs. Future research should be carried out in order to evaluate their activity budgets, a genetic study and diet through metabarcoding approaches to promote their domestication.

\section{Ethics approval and consent to participate}

Ethical guidelines of the International Society of Ethnobiology(http://www.ethnobiology.net/) were strictly followed. All participants were asked for their free prior informed consent before interviews were conducted.

\section{Consent for publication}

The present paper does not contain any individual person's data; therefore, this section is not applicable to our study.

\section{Availability of data and material}

All data have already been included in the manuscript. We are willing to share the data generated and analyzed during the current study.

\section{Competing interests}

The authors declare that they have no competing interests.

\section{Funding}

This paper is a part of a PhD's thesis by Mr. Florian Gbodja Codjia. Our gratitude goes to the "Doctoral Student Support Programme (PAD) 2017-2018" of the Beninese government for having made some financial means available for the data collection.

\section{Authors' contribution}

TOL has identified the need for this work as a primary basis future research. FGC was able to collect the data and then analyzed all them which allowed him to write this manuscript under the supervision of TOL, SDFL and GAM. 


\section{ACKNOWLEDGMENTS}

We would like to thank the local population living in the different localities we visited for facilitating the field work and the Benin General Directorate of Water, Forests and Hunting (DGEFC) for the research authorization.

\section{REFERENCE}

[1] W. Oliveira, M. Luna, W. Souto, and R. R. N. Alves, "Interactions between people and game mammals in a Brazilian semi-arid area," Indian J. Tradit. Knowl., vol. 16, pp. 221-228, 2017.

[2] S. Wolverton, J. H. Kennedy, and J. D. Cornelius, “A paleozoological perspective on white-tailed deer (Odocoileus virginianus texana) population density and body size in central Texas," Env. Manag., vol. 39, no. 4, pp. 545-552, 2007.

[3] A. C. Diegues, "Pescadores, camponeses e trabalhadores do mar," São Paulo Ática, 1983.

[4] N. A. L. -Neto, R. A. Voeks, T. L. P. Dias, and R. R. N. Alves, "Mollusks of Candomblé: symbolic and ritualistic importance," J. Ethnobiol. Ethnomed., vol. 8, no. 1, p. 10, 2012, doi: 10.1186/1746-4269-8-10.

[5] R. R. N. Alves, E. L. S. Mota, and T. L. P. Dias, "Use and commercialization of animals as decoration. In: Alves RRN, Albuquerque UP (eds) Ethnozoology: Animals in Our Lives. 1 edn. Academic Press - Elsevier, London, pp. 261--275,” 2018.

[6] R. R. N. Alves, I. L. Rosa, N. A. L. Neto, and R. Voeks, "Animals for the gods: magical and religious faunal use and trade in Brazil," Hum Ecol, vol. 40, pp. 751-80, 2012, doi: 10.1007/s10745-012-9516-1.

[7] L. R. Larson, A. L. Conway, S. M. Hernandez, and J. P. CArroll, "Human-wildlife conflict, conservation attitudes and a potential role for citizen science in Sierra Leone, Africa," Conserv. Soc., vol. 14, pp. 205-217, 2016.

[8] H. Yasuoka, "The sustainability of duiker (Cephalophus spp.) hunting for the baka hunter-gatherers in Southeastern Cameroon," Afr. Stud. Monorg, vol. 33, pp. 95-120, 2006.

[9] A. J. Plumptre, D. Kujirakwinja, and S. Nampindo, "Conservation of landscapes in the Albertine Rift. Protected areas, governance and scale. In:," Wildl. Conserv. Soc. Bronx, New York, pp. 27-34, 2008. 
[10] D. Kujirakwinja, "The status and conservation of common hippopotamuses in Virunga National Park, Democratic Republic of Congo," University of Cape Town, Percy Fitzpatrick Institute of African Ornithology, South Africa. , p. 60, 2010.

[11] R. Alves and H. Alves, "The faunal drugstore: Animal-based remedies used in traditional medicines in Latin America," J. Ethnobiol. Ethnomed., vol. 7, no. 9, pp. 143, 2011.

[12] E. M. Costa-Neto, "Entomotherapy, or the medicinal use of insects," J. Ethnobiol., vol. 25, pp. 93-114, 2005, doi: 10.2993/0278-0771(2005)25[93:EOTMUO]2.0.CO;2.

[13] C. A. M. S. Djagoun, H. A. Akpona, G. A. Mensah, C. Nuttman, and B. Sinsin, "Wild mammals trade for zootherapeutic and mythic purposes in Benin (West Africa): capitalizing species involved, provision sources, and implications or conservation. In: Alves RRN, Rosa IL, editors. Animals in traditional folk medicine," Heidelberg, Springer-Verlag Berlin, p. 367-81, 2013.

[14] F. G. Codjia, T. O. Lougbegnon, A. G. Mensah, and J. T. C. Codjia, "Place du potamochère roux et du phacochère commun au Bénin parmi les Suidés : synthèse bibliographique," Bull. mens. Soc. linn. Lyon, vol. 89, no. 5-6, pp. 61-87, 2020, [Online]. Available: http://www.linneenne-lyon.org/spip3/spip.php?article1957.

[15] R. Alves and S. Silva, "Ethnozoology: A Brief Introduction," Etnobiol. Conserv., vol. 4, pp. 1-13, 2015.

[16] M. E. Dossou, T. O. Lougbegnon, G. L. Houessou, and J. T. C. Codjia, "Ethnozoological uses of common hippopotamus (Hippopotamus amphibius) in Benin Republic (Western Africa),” Indian J. Tradit. Knowl., vol. 17, no. 1, pp. 85-90, 2018.

[17] K. Macdonald and C. Sillero-Zubiri, "Large carnivores and conflict: lion conservation in context. In: Lion conservation research, Workshop 2 - modelling conflict. Eds. Loveridge, A.J., T. Lynam and D.H. MacDonald," Wildl. Conserv. Res. Unit, Oxford Univ., Oxford, UK, pp. 1-8, 2002.

[18] A. Granados and R. Weladji, "Human-elephant conflict around Benoue National Park, Cameroon: influence of local attitudes and implications for conservation," Hum. Dimens. Wildl., vol. 17, no. 2, pp. 77-90, 2012.

[19] D. Beaune, L. Bollache, B. Fruth, and F. Bretagnolle, "Bush pig (Potamochoerus porcus) seed predation of bush mango (Irvingia gabonensis) and other plant species in Democratic Republic of Congo," Afr. J. Ecol, vol. 50, pp. 509-512, 2012. 
[20] W. Oliver, "Taxonomy and conservation status of the Suiformes-an overview," IBeX J. Mt. Ecol., vol. 3, pp. 3-5, 1995.

[21] N. V Vliet, R. Nasi, L. Emmons, F. Feer, P. Mbazza, and M. Bourgarel, "Evidence for the local depletion of bay duiker Cephalophus Dorsalis, Within the ipassa man and biosphere reserve, north-east Gabon," Afr. J. Ecol, vol. 45, pp. 440-443, 2007.

[22] T. Breuer, F. B. M. Mireille, and B.-N. Hockemba, "Dung decay and its implication for population estimates of duikers (Cephalophus and Philantoba spp.) and red river hogs (Potamochaerus porcus) in the Nouabale'-Ndoki National Park, Republic of Congo," Afr. J. Ecol, vol. 48, pp. 551-554, 2009.

[23] M. D. Agassounon, "Ecologie alimentaire du phacochère (Phacochoerus africanus, Gmelin 1788) dans la forêt classée de Wari-Maro au Bénin," Mémoire de 3è cycle DESS/FSA/UAC, Abomey-Calavi. p 85, 2005.

[24] J. T. C. Codjia, M. R. Ekue, and S. K. Conde, L'habitat du phacochère (Phacochoerus africanus) dans la forêt classée des Trois Rivières au Bénin. In : Quelles aires protégées pour l'Afrique de l'Ouest? Conservation de la biodiversité et développement, IRD. Marseille, 238-246 pp, 2007.

[25] C. K. Adjin, T. O. Lougbegnon, J. T. C. Codjia, and G. A. Mensah, "Distribution, caractérisation écologique de l'habitat et notes sur le régime alimentaire du phacochère commun, Phacochoerus africanus (Gmelin, 1788) au Sud du Bénin," Int. J. Biol. Chem. Sci., vol. 5, pp. 1907-1921, 2011.

[26] D. H. M. Houehounha, "Etude de l'abondance et de la répartition géographique de Potamochoerus porcus dans la forêt classée de la Lama au Sud du Bénin," Institut Polytechnique Rural de Formation et de Recherche Appliquee (IPR/IFRA) de Katibougou, p 85, 2011.

[27] INSAE, “Rgph4 : Que Retenir Des Effectifs De Population En 2013 ?,” 2015.

[28] F. G. Codjia, O. T. Lougbegnon, M. Labra, and M. E. Dossou, "Safeguarding of Benin wild pigs habitats to increase the resilience of spontaneous and marginal populations," Moroccan J. Agric. Sci., vol. 1, no. 6, pp. 305-316, 2020, [Online]. Available: www.techagro.org.

[29] P. Dagnelie, "Statistiques théoriques et appliquées," Brussels: De Boeck et Larcier, 1998.

[30] H. Akpona, C. A. M. S. Djagoun, and B. Sinsin, "Ecology and ethnozoology of the three-cusped pangolin Manis tricuspis (Mammalia, Pholidota) in the Lama forest 
reserve, Benin," Mammalia, vol. 72, pp. 198-202, 2008, doi:

10.1515.MAMM.208.046.

[31] L. G. Houessou, T. O. Lougbegnon, F. G. H. Gbesso, L. E. S. Anagonou, and B. Sinsin, "Ethno-botanical study of the African star apple ( Chrysophyllum albidum G . Don ) in the Southern Benin ( West Africa )," J. Ethnobiol. Ethnomed., vol. 8, no. 40, pp. 1-10, 2012, doi: 10.1186/1746-4269-8-40.

[32] O. Lougbegnon, "Ecologie et connaissances ethnozoologiques de quelques especes d'oiseaux gibiers menaces des ecosystemes du sud du benin. In: Biologie, Ecologie et Evolution," Université de LIEGE, p. 146, 2015.

[33] J. Friedman, Z. Yaniv, A. Dafni, and D. Palewitch, "A preliminary classification of the healing potential of medicinal plants, based on a rational analysis of an ethno pharmacological field survey among Bedouins in the Negev Desert," Isr. J. Ethnopharmacol, vol. 16, pp. 275-287, 1986.

[34] O. Philips and A. Gentry, "The useful plants of Tambopata Peru. II Statistical hypothesis tests with a new quantitative technique," Econ. Bot, vol. 47, pp. 33-43, 1993.

[35] N. Nagelkerke, "A note on a general definition of the coefficient of determination," Biometrika, vol. 78, pp. 691-692, 1991.

[36] M. Nakazawa, "fmsb: Functions for medical statistics book with some demographic data," $R$ Packag. version 0.5.0. https//CRAN.R-project.org/package=fmsb, 2014.

[37] E. L. Y. Loko, S. M. Fagla, A. Orobiyi, B. Glinma, and J. Toffa, "Traditional knowledge of invertebrates used for medicine and magical - religious purposes by traditional healers and indigenous populations in the Plateau Department, Republic of Benin," J. Ethnobiol. Ethnomed., vol. 15, no. 66, pp. 1-21, 2019, doi: 10.1186/s13002019-0344-x.

[38] K. S. Bobo, F. Florence, M. Aghomo, and B. C. Ntumwel, "Wildlife use and the role of taboos in the conservation of wildlife around the Nkwende Hills Forest Reserve; South-west Cameroon Wildlife use and the role of taboos in the conservation of wildlife around the Nkwende Hills Forest Reserve ; South-west Came," J. Ethnobiol. Ethnomed., vol. 11, no. 2, p. 23, 2014, doi: 10.1186/1746-4269-11-2.

[39] R. Duda, S. Gallois, and V. Reyes-garcía, "Ethnozoology of bushmeat: Importance of wildlife in diet, food avoidances and perception of health among the Baka (Cameroon)," Rev. d'ethnoécologie, vol. 14, p. 41, 2018, doi:

10.4000/ethnoecologie.3976. 
[40] F. A. Kendie, S. A. Mekuriaw, and M. A. Dagnew, "Ethnozoological study of traditional medicinal appreciation of animals and their products among the indigenous people of people of Metema Woreda, North-Western Ethiopia," J. Ethnobiol. Ethnomed., vol. 14, no. 37, pp. 1-12, 2018, doi: 10.1186/s13002-018-0234-7.

[41] T. Haileselasie, "Traditional zootherapeutic studies in Degu'a Tembien, Northern Ethiopia," Curr Res J Biol Sci, vol. 4, no. 5, pp. 563-9, 2012.

[42] M. Swanepoel, E. Schulze, and D. H. M. Cumming, "A conservation assessment of phacocheorus africanus.," Red List South Africa, Swazil. Lesotho. South African Natl. Biodivers. Inst. Endangerd Wildl. Trust. South Africa, 2016.

[43] J. E. Fa and D. Brown, "Impacts of hunting on mammals in African tropical moist forests: a review and synthesis," Mammal Rev, vol. 39, pp. 231-264, 2009.

[44] R. Amin, T. Wacher, and T. Butynski, "Sympatry Among Three Suid Species (Family Suidae) On The North Coast Of Kenya," J. East African Nat. Hist., vol. 106, pp. 6778, 2017.

[45] O. Awojoodu and D. Baran, "Traditional Yoruba medicine in Nigeria: a comparative approach,” Bull. Transilv. Univ. Braşov, vol. 6, no. 51, pp. 129-36, 2009.

[46] O. Taye, "Yoruba traditional medicine and the challenge of integration," J.Pan. Afr. stud, vol. 3, no. 3, pp. 73-98, 2009.

[47] E. Ajagun, C. Anyaku, and M. Afolayan, "A survey of the traditional medical and nonmedical uses of animals species and parts of the indigenous people of Ogbomoso, Oyo State," Int. J. Herbal. Med, vol. 5, no. 3, pp. 26-32, 2017.

[48] N. Coulibaly, "Valeurs socioculturelles du poisson : thérapie et mysticisme," Carrefour Afr., vol. 1128, p. 18, 2006.

[49] A. Camou-Guerrero, V. Reyes-Garcia, M. Martinez-Ramos, and A. Casas, "Knowledge and use value of plant species in a Raramuri community: a gender perspective for conservation," Hum. Ecol, vol. 36, pp. 259-272, 2008.

[50] N. Hanazaki, R. Alves, and A. Begossi, "Hunting and use of terrestrial fauna used by Caicaras from the Atlantic Forest coast (Brazil)," J. Ethnobiol. Ethnomed, vol. 4, p. 36, 2009.

[51] F. G. Codjia, "Determinants of the abundance of the common hippopotamus Hippopotamus amphibius ( Linnaeus , 1758 ) in the Mono-Benin Biosphere Reserve," 
Master Thesis. University of Abomey-calavi, Faculty of Agricultural Science. p53, 2018.

[52] B. Vodouhê, F. G., Coulibaly, O., Adégbidi, A., \& Sinsin, "Community perception of biodiversity conservation within protected areas in Benin," For. Policy Econ., vol. 12, no. 7, pp. 505-512, 2010.

[53] C. Ward, L. C. Stringer, and G. Holmes, "Protected area co-management and perceived livelihood impacts," J. Environ. Manage., vol. 228, pp. 1-12, 2018.

[54] M. Lindsey, P., Allan, J., Brehony, P., Dickman, A., Robson, A., Begg, C., ... \& Flyman, "Conserving Africa's wildlife and wildlands through the COVID-19 crisis and beyond," Nat. Ecol. Evol., vol. 4, no. 10, pp. 1300-1310, 2020. 


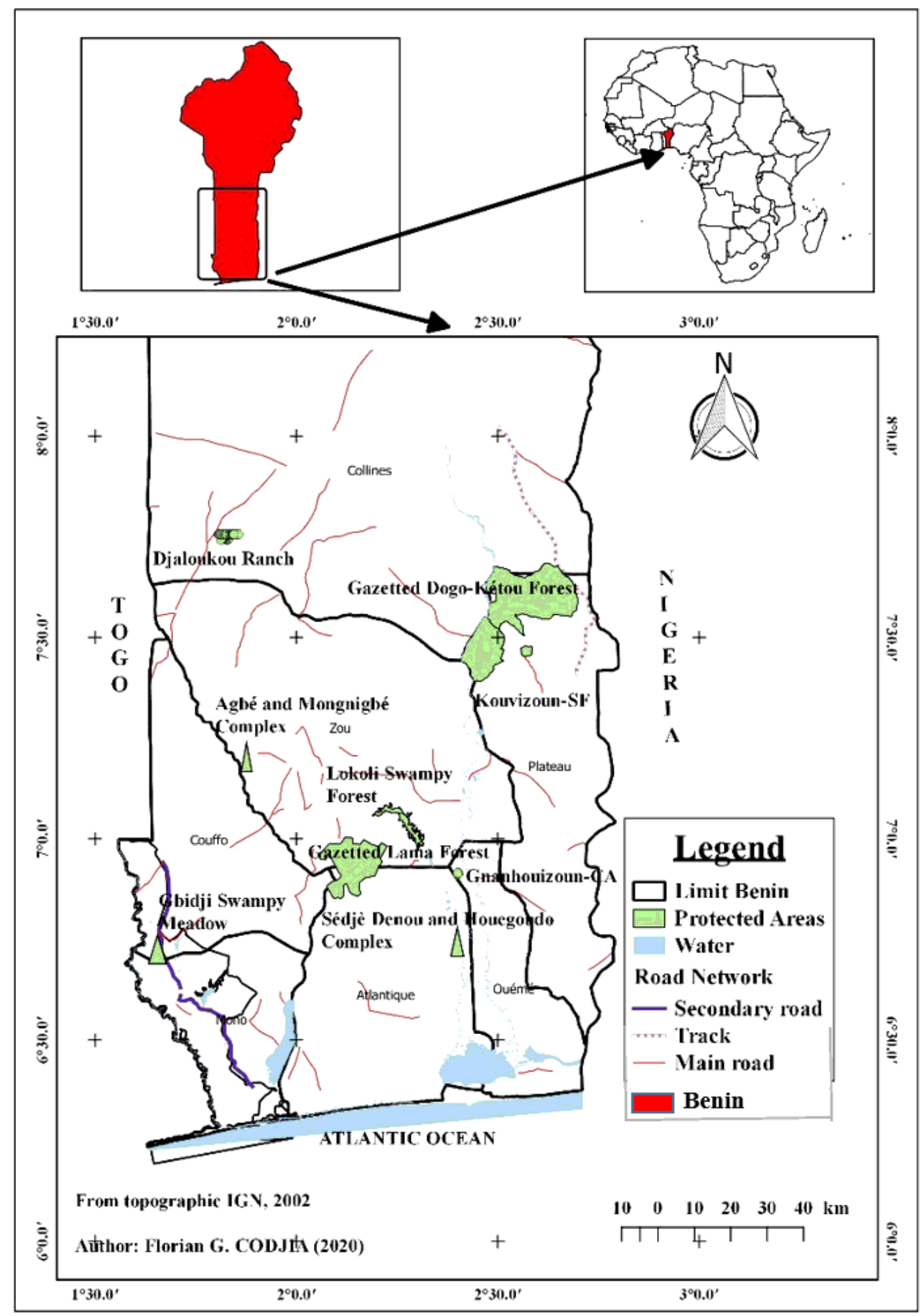

\section{Figure 1}

Map of study area showing the distribution of studied sites located in the Plateau Department, Benin. Note: The designations employed and the presentation of the material on this map do not imply the expression of any opinion whatsoever on the part of Research Square concerning the legal status of any 
country, territory, city or area or of its authorities, or concerning the delimitation of its frontiers or boundaries. This map has been provided by the authors.

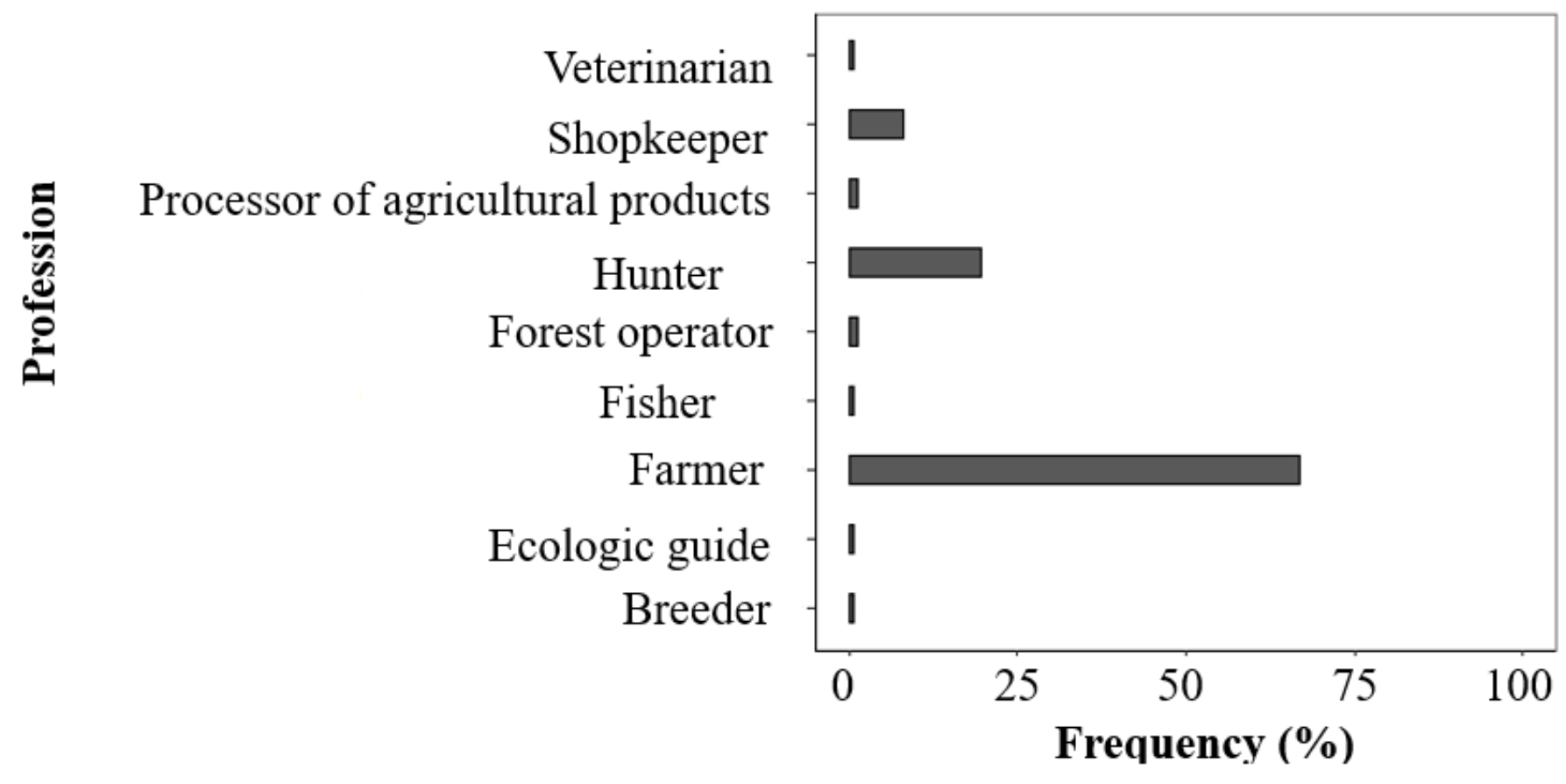

Figure 2

Profession of respondents of six studied communities in Benin. 


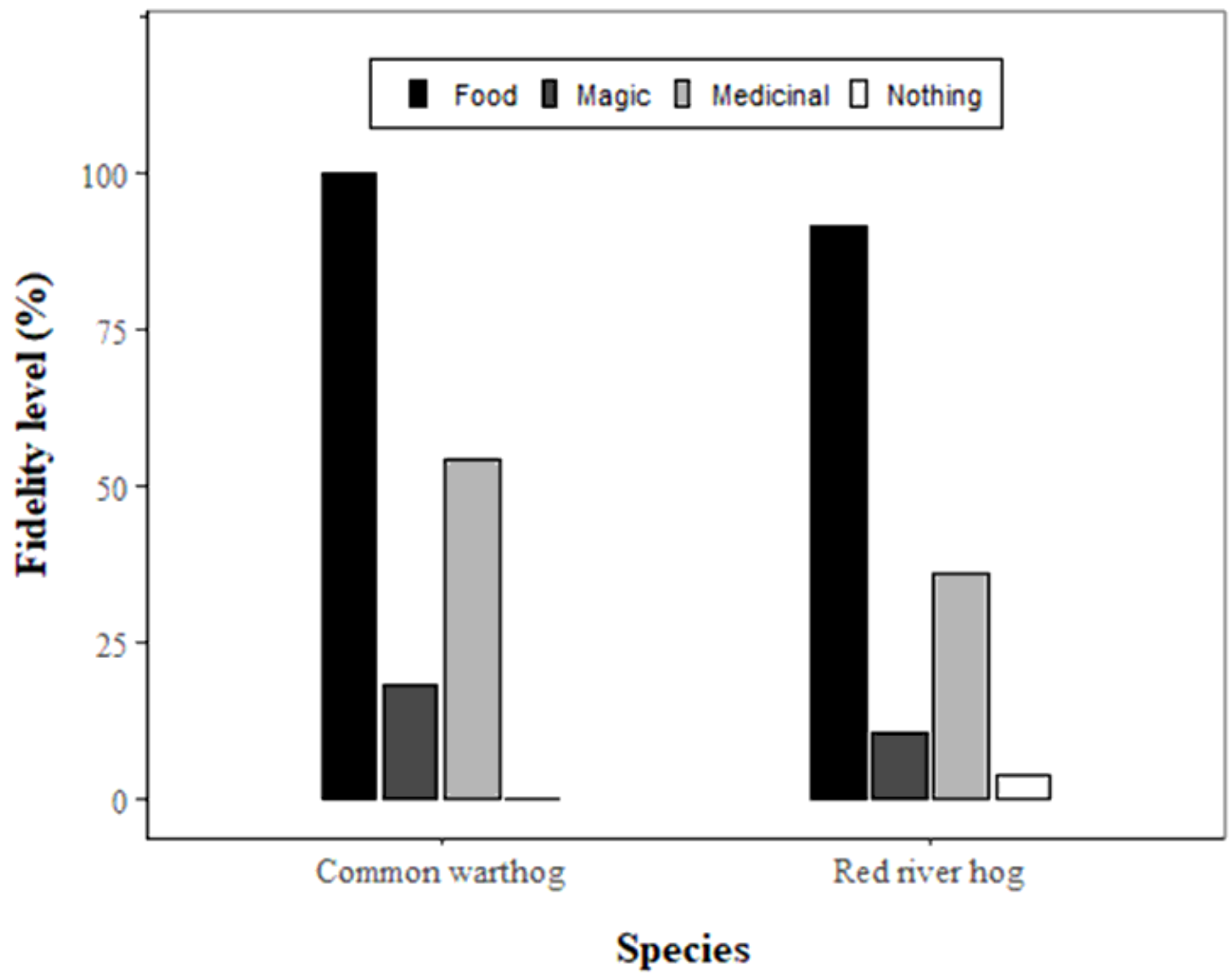

Figure 3

Fidelity level by use category for each suids species studied.

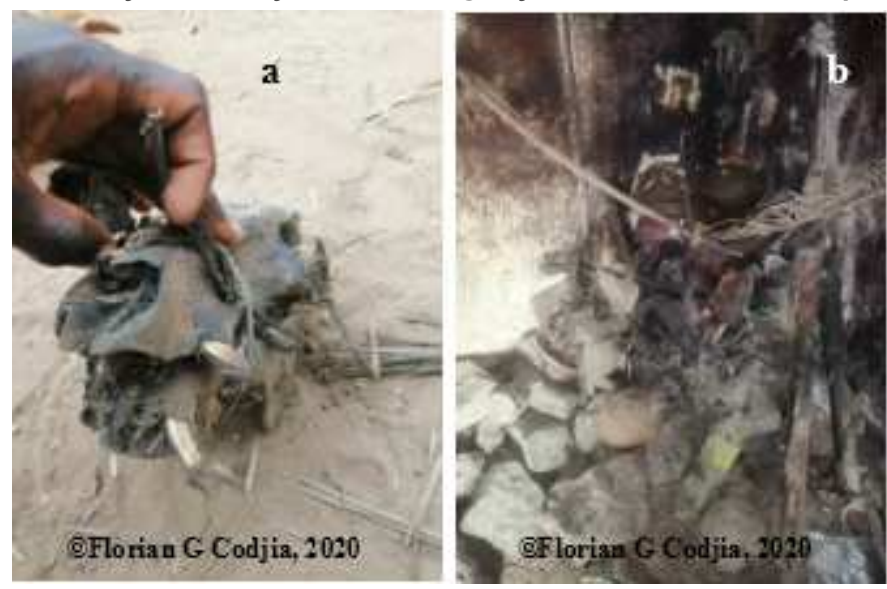

Figure 4 
(a) Full Red river hog skull with its hooks used against witchcraft in Sedje-Denou; (b): common Warthog hooks used to erect vodoun and fight against witchcraft in Djalokou.
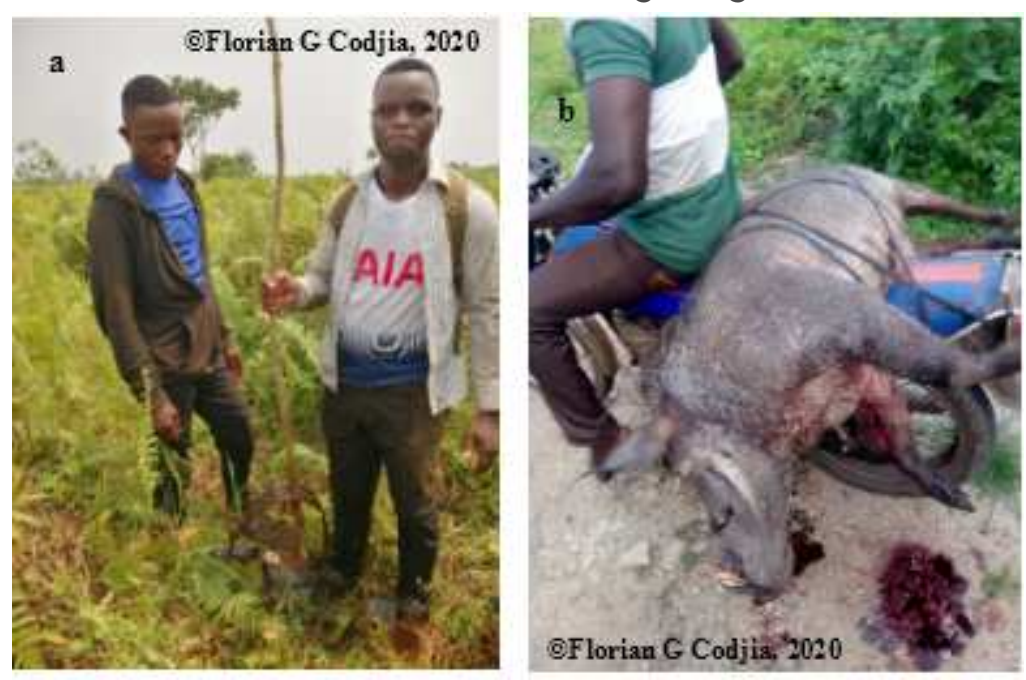

\section{Figure 5}

(a) Red river hog trap installed in the Sedje-Denou and Houegoudo complex; (b): common Warthog subadult individual killed at the Agbe and Mongnigbe complex (Agbokpa) after three consecutive hunting days.

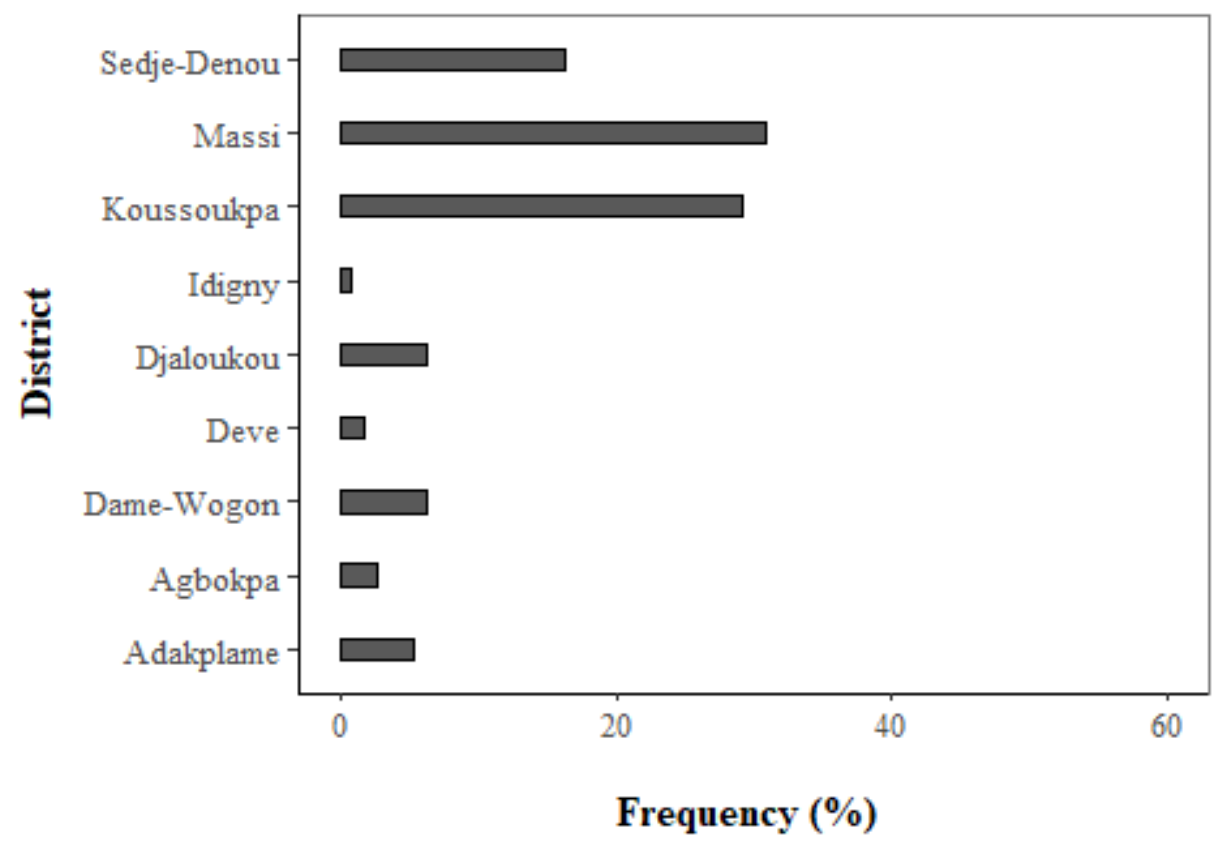

Figure 6

Desire for the suids conservation by district studied in Benin. 


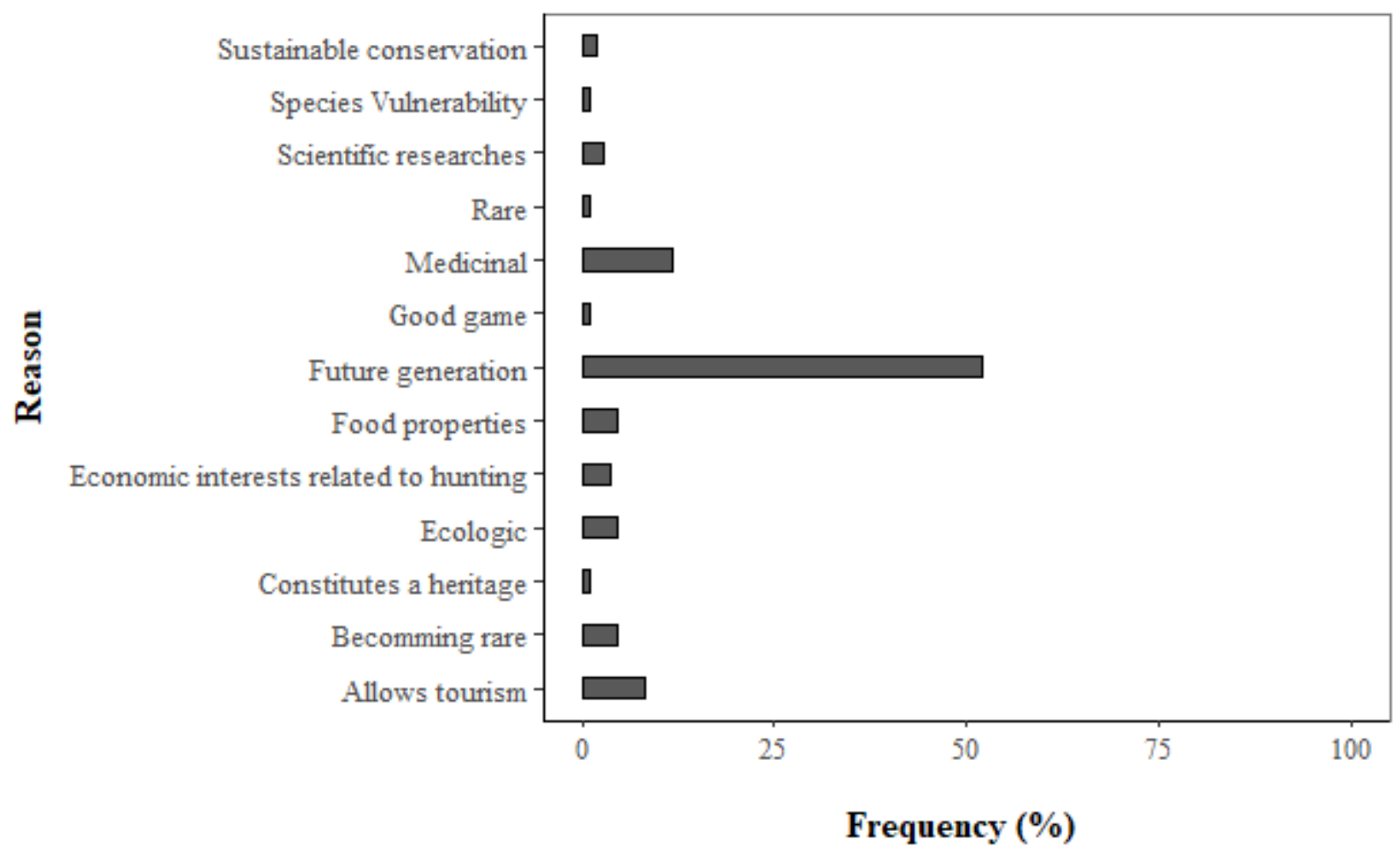

Figure 7

Reason for the desire to preserve suids studied in Benin. 


\section{CA factor map}

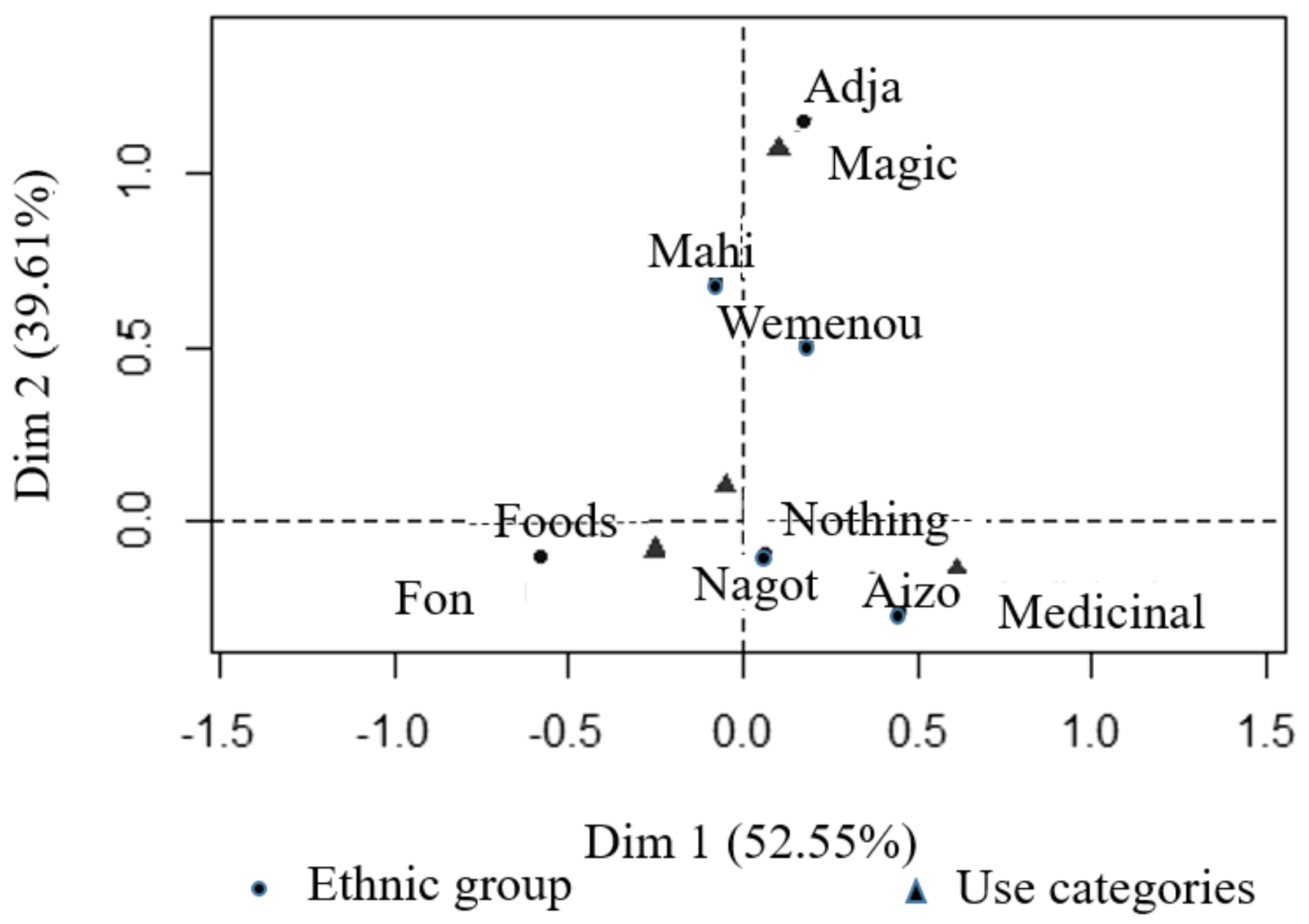

Figure 8

Projection of PCA results for use and ethnic group categories on the first two factor axes. 


\section{CA factor map}

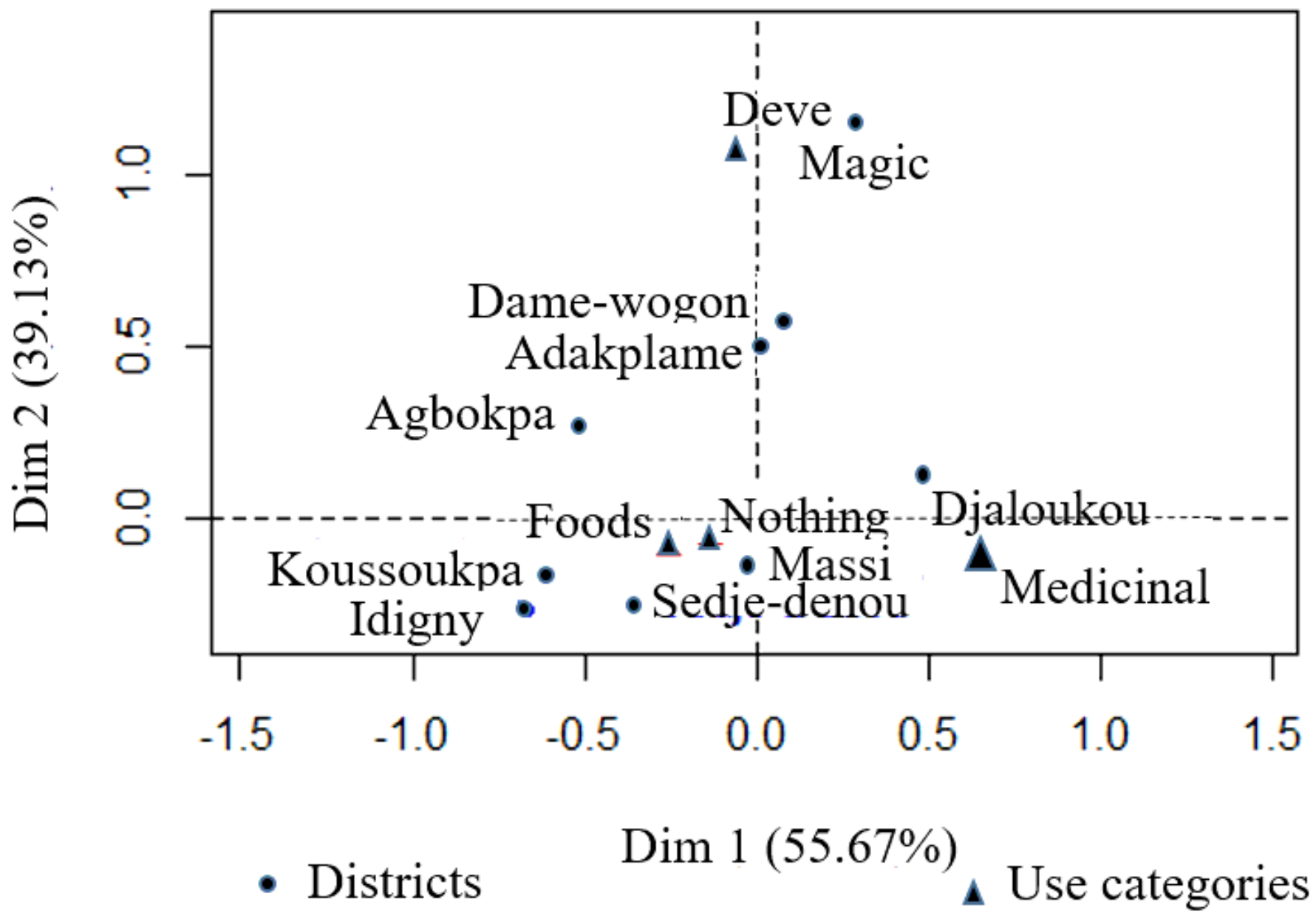

Figure 9

Projection of PCA results for use categories and districts on the first two factor axes. 